
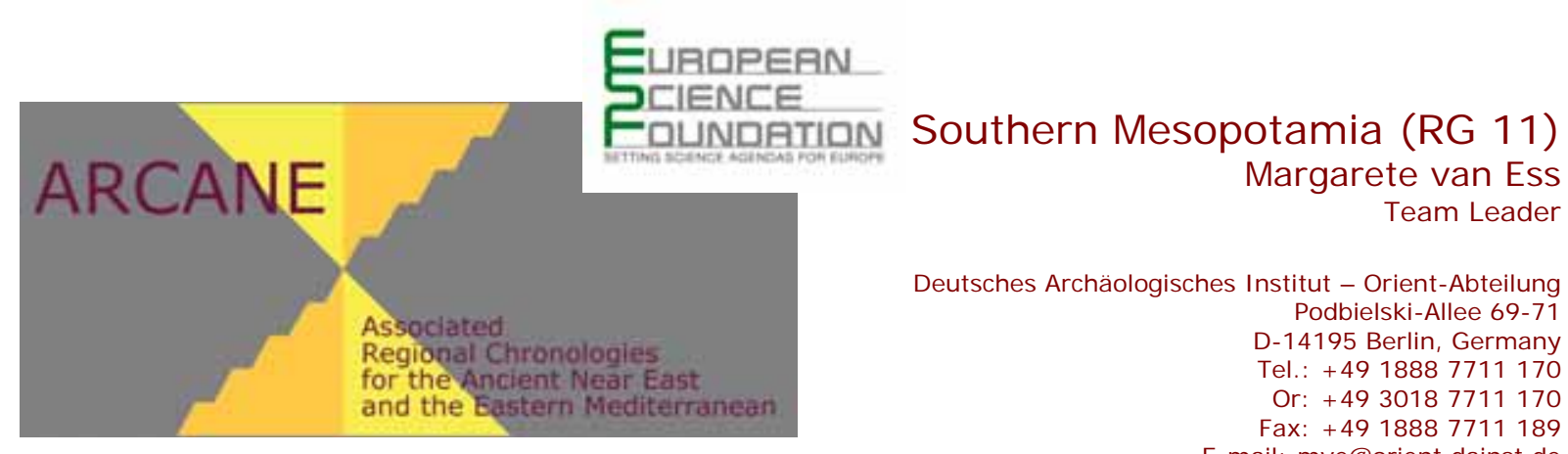

Deutsches Archäologisches Institut - Orient-Abteilung Podbielski-Allee 69-71 D-14195 Berlin, Germany Tel.: +49 18887711170 Or: +4930187711170 Fax: +4918887711189 E-mail: mve@orient.dainst.de

Second international meeting of the Regional Group 11 „Southern Mesopotamia“

Workshop Blaubeuren 5-9 February 2009

\title{
Scientific Content
}

\section{Presentation of developments of the ARCANE database}

The Chairman of the ARCANE project, Professor Marc Lebeau, presented the latest technical developments of the database used for the project. His presentation especially focused on the possibilities and strategies for queries in the database needed for the second phase of ARCANE. The technical team, METRA, summarized several technical details several members of the Project were not aware or defined in different ways. Some time was spent to adjust data input according to the guidelines of the project which, however, in several cases are not equally applicable or adjusted to the traditions of archaeological methodology of the different regions and therefore were understood partly in different ways. Consistency of data input, nevertheless, is crucial for a subsequent sensible use of the database.

This part of the meeting was held as a common meeting of the three ARCANE groups gathering in Blaubeuren (see program).

2. Update of the presentation and discussion of stratigraphically and chronologically relevant materials

For Southern Mesopotmia, considerable time of discussion was spent to summarize the efforts that have been reached during the last months of work. Well stratified material from Southern Mesopotamia is difficult to obtain because of the difficulty that due to the political situation only few excavations were carried out during the last 30 years and according to the modern technical standards that are prerequisite for a project like ARCANE. On the other hand, epigraphical and historical data relevant for absolute chronological frameworks still are mainly available from Mesopotamia. Therefore, on the one hand a drastic revision of the sites excavated several decennias ago for stratigraphically reliable material had to be carried out and, on the other hand, collection of stratified material from those excavations which were carried out since the 1980ies.

Having contacted several colleagues who either excavated at relevant sites in Southern Mesopotamia or analyzed older excavations reports the former list of formerly 19 possibly relevant sites was shortened to eight sites: SM002 Tell Wilaya, SM003 Abu Salabikh, SM 
004 Nippur, 010 Fara, 011 Jokha, 014 Tell Hiba, 015 Uruk, 016 Senkere. All other sites do contribute to $3^{\text {rd }}$ millennium BC history but either do not offer sufficiently stratified material or the material was not available mainly for political reasons connected to the special situation of Iraq.

One of the problems of these sites is that overlap of periods is rather rare. In addition, the amount of reliable material is limited. It is, therefore, difficult to compare material in detail and, consequently, difficult to offer proposals for a revised chronology. The available material was presented and discussed in some detail. Material which has some chronological relevance consists - beside architectural evidence - mainly of pottery, stone vessels, some lithic artefacts and some seal impressions or cylinder seals. Furthermore, problems and challenges of this review of material has be discussed. One result was that the stratigraphical determination especially of epigraphical and textual material is much worse than thought before. In addition, none of the sites offer possibilities for new C14 dates.

It was decided to partly join meetings with the Central Mesopotamian Group in order to raise the number of possible overlaps of periods and in order to discuss with the colleagues the known - chronological problems between both regions.

3. Attempt at a definition of a periodisation according to ARCANE guidelines and discussion of methodological problems

Jointly with the Central Mesopotamia Group existing periodisations were discussed regarding their problems and recent research which partly revised long established development definitions. One of the periods that needs intensive discussion is the Early Dynastic II period. While from the Diyala region serious arguments have been developped to eliminate that period, in the central region between the Euphrates and the Tigris there are good arguments for the existence and further definition of it.

New data important for Southern Mesopotamia, come from Mari in Northeastern Syria, where data from older excavations have been revised and resulted in new internal periodisations recently.

Exchange of data and views was extremely helpful and should be continued during the next months. One even should think about a joint publication of the results of both groups because this would make the current state of scholarly discussions and problems much more understandable than presenting the material of the two groups in different volumes.

\section{Presentation of the regional results; attempt at a preliminary periodisation}

Discussions were summarized and presented in common meetings for discussion. While a preliminary periodization for the Southern Mesopotamian and the Central Mesopotamian Group has been developped, focus had to be laid on the fact that this periodization is still preliminary and should be presented to the public yet.

Everybody agreed that all involved scholars now have to go back to the material of the respective sites and re-evaluate what has been discussed during the meetings. Only with indepth re-evaluation as well of long established and recently re-structured proposals for periodizations it will be possible to gain a substantial and well founded revised periodization for the two regions. 


\begin{tabular}{|c|c|c|c|c|c|c|c|c|}
\hline Mainstream & JN & ED I & ED II & ED III a & ED III b & Early Akkad & Later Akkad-Guti ( ?) a & Ur III \\
\hline SOUTHERN & ESM 1 & ESM 2/3 & ESM 4 & ESM 5 & ESM 6 & ESM 7 & ESM 8 & ESM 9 \\
\hline $\begin{array}{l}\text { MESOPOTAMIA } \\
\text { URUK }\end{array}$ & $\mathrm{K} / \mathrm{L} 12$ & K/L 12 Fanna & & & & & & Fanna \\
\hline AL НIвBAH & & Area G & & & Area C, A & & & \\
\hline FARA & $\begin{array}{c}\text { DE } \\
38 / 39\end{array}$ & $\begin{array}{c}\text { DE } \\
38 / 39\end{array}$ & $\begin{array}{c}\text { DE } \\
38 / 39\end{array}$ & Trench 13 E-G & & & & \\
\hline ABU SALABIKH & $3 \mathrm{G}-81$ & $\begin{array}{c}\text { 2G 032 G 36, } 6 \text { G } \\
54 / 64, \text { gr } 160 \text { GR } \\
193 \\
\end{array}$ & $\begin{array}{c}6 \mathrm{H}-82 \\
6 \mathrm{G} 54 / 64\end{array}$ & $\begin{array}{c}\text { Area E } \\
\text { Central C }\end{array}$ & $\begin{array}{l}\text { Ash tip } \\
\text { Graves }\end{array}$ & & & \\
\hline NIPPUR & I-T $14-12$ c & I-T 11-9 & $\mathbf{X}$ & $\begin{array}{c}\text { I-T 8-7 b } \\
\text { WF XIX-XVIII } \\
\end{array}$ & WF-XVII........ & WF........XV & $\begin{array}{l}\text { WA } 50 \text { c } \\
\text { WF XIV-XI }\end{array}$ & $\begin{array}{l}\text { WC -9 } \\
\text { WF XI-IX }\end{array}$ \\
\hline \multicolumn{9}{|l|}{ LARSA } \\
\hline WILAYA & & & & Area $15 \mathrm{~L}$ & & & Area $27 \mathrm{H}$ & Area $27 \mathrm{H}$ \\
\hline UMMA & & & & & & & & Area 1 Shara \\
\hline $\begin{array}{c}\text { CENTRAL } \\
\text { MESOPOTAMIA }\end{array}$ & ECM 1 & ECM 2/3 & ECM 4 & ECM 5 & ECM 6 & ECM 7 & ECM 8 & ECM 9 \\
\hline ASMAR & $\begin{array}{c}\text { Abu } \\
\text { Earliest shrine }\end{array}$ & $\begin{array}{l}\text { Abu Archaic } \\
\text { Shrine I-IV, } \\
\text { SquareTemple I }\end{array}$ & $\mathbf{X}$ & $\begin{array}{l}\text { Abu Square } \\
\text { Temple II-III }\end{array}$ & $\begin{array}{l}\text { Abu Single Shrine I } \\
\text { Earlier NP }\end{array}$ & $\begin{array}{l}\text { Abu Single Shrine } \\
\text { II-III,Earlier NP } \\
\text { Houses V- c-a }\end{array}$ & $\begin{array}{c}\text { Abu Single Shrine IV } \\
\text { Main NP } \\
\text { Houses IV b-a } \\
\end{array}$ & $\begin{array}{l}\text { "Akkad " } \\
\text { Houses } \\
\text { Shu-Sin }\end{array}$ \\
\hline KHAFADJE & $\begin{array}{l}\text { Sin I-III } \\
\text { Houses } 12 \text { and } \\
\text { below }\end{array}$ & $\begin{array}{c}\text { Sin IV-VII } \\
\text { Houses XI-VII }\end{array}$ & $\mathbf{X}$ & $\begin{array}{l}\text { Sin VIII-IX } \\
\text { Houses 6-3 }\end{array}$ & $\begin{array}{c}\text { Sin X } \\
\text { Houses } 2\end{array}$ & $\begin{array}{c}\text { Houses } 1 \\
\text { Oval } 3\end{array}$ & & \\
\hline ASHUR & & & & AIT H & & AIT G, F, graves & $\begin{array}{c}\text { AIT G,F, } \\
\text { CTS IIIB 5- 24, graves }\end{array}$ & $\begin{array}{c}\text { AIT, CTS } \\
\text { III B } 3, \text {,E, graves }\end{array}$ \\
\hline MARI & & $\begin{array}{c}\text { Ville } 1 \\
\text { Chantier L }\end{array}$ & Tomb 300 & $\begin{array}{c}\text { Ville } 2 \\
\text { Chantier N } 1 \\
\text { Maquette F } \\
\end{array}$ & $\begin{array}{c}\text { Ville } 2 \text { (later), P1 } \\
\text { Massif rouge } 3 \\
\text { Nini zazaTemple } \\
\end{array}$ & Palace P O & $\begin{array}{l}\text { Mature Akkad/Ville 3, } \\
\text { Lion } \\
\text { Temple,ChantieF,graves }\end{array}$ & $\begin{array}{l}\text { Ville 3,Sahuru,Palais } \\
\text { oriental Graves }\end{array}$ \\
\hline ЈОКНА & & & $\begin{array}{c}\text { Jokha } 3 \\
\text { 5-7 c, D,E } \\
\text { 5-8 F, 6-8 G }\end{array}$ & $\begin{array}{c}\text { Jokha } 2 \\
\text { 5-7 D, E, } \\
\text { 5-8 F, 6-8 G }\end{array}$ & & & & \\
\hline RAZUK & & $\begin{array}{c}\text { Round building } \\
\text { houses }\end{array}$ & & & & burials & & \\
\hline ATIQAH & & & & & & Atiqah 3-2 & Atiqah 1 & \\
\hline GUBBA & $\begin{array}{l}\text { Round building } \\
\text { VII }\end{array}$ & VI-IV & & & & & & \\
\hline YELKI & & & & & & & Level VIII & \\
\hline KHEIT QASIM & & Graves/ cemetery & & & & & & \\
\hline AHMED AL HATTU & & $\mathbf{X}$ & & & & & & \\
\hline KISH & & & & $\begin{array}{c}\text { Palace A } \\
\text { Burials }\end{array}$ & Burials & Burials & & \\
\hline
\end{tabular}


If possible, one therefore should arrange for another internal meeting of the two groups before publishing results.

5. Guidelines for the publications, Deadlines and other organisational questions

The workshop ended with a common meeting of all three ARCANE groups. Recent informations about the guidelines for the publications were presented and discussed (see the relevant written paper). Deadlines as well for the input and correction of data in the database as well as for a publication were presented and the nexts steps for the interregional phase of the ARCANE project outlined and scheduled. 